\title{
PENGEMBANGAN BUKU IPA BERBASIS KEARIFAN LOKAL JAMBI PADA MATERI TEKANAN SERTA GETARAN DAN GELOMBANG
}

\section{DEVELOPMENT OF SCIENCE BOOK BASED ON JAMBI LOCAL WISDOM IN THE MATERIAL OF PRESSURE AND VIBRATION AND WAVES}

\author{
Jufrida $^{1}$, Fibrika Rahmat Basuki ${ }^{2}$, Anta Xena ${ }^{3}$, Pretty Pasminingsih ${ }^{4}$ \\ ${ }^{1,2}$ Program Studi Pendidikan Fisika Universitas Jambi \\ ${ }^{3,4}$ SMPN 1 Muaro Jambi \\ E-mail: fibrikabika@yahoo.com
}

Diterima: 11 Agustus 2019. Disetujui: 10 Oktober 2019. Dipublikasikan: 29 November 2019

\begin{abstract}
This study aims to develop science books based on Jambi local wisdom and improve student learning motivation. This research was a research and development using ADDIE model. The subjects were material experts, media experts and class VIII students of SMPN 1 Muaro Jambi, totaling 30 students. The instruments used in this study were observation sheets, questionnaire needs, material and media validation sheets and student motivation questionnaires. Qualitative data were analyzed descriptively and quantitative data were analyzed using descriptive statistics. This study produced a science book based on Jambi local wisdom about the pressure and vibration and waves. Local wisdom was used as a context to explore scientific concepts. The results of the material expert validation obtained an average score of 4.5 with the category "very good" and the media expert was 4.65 with the category "very good". The results of field trials show that science books based on Jambi local wisdom can increase students' learning motivation with an average score of 4.1 (good category).
\end{abstract}

Keywords: science books, jambi local wisdom, student motivation.

Abstrak: Penelitian ini bertujuan untuk mengembangkan buku IPA berbasis kearifan lokal Jambi serta meningkatkan motivasi belajar siswa. Penelitian ini merupakan penelitian pengembangan. Subjek penelitian adalah ahli materi, ahli media serta siswa kelas VIII di SMPN 1 Muaro Jambi yang berjumlah 30 siswa. Instrumen yang digunakan dalam penelitian ini lembar observasi, angket kebutuhan lembar validasi ahli materi dan media serta angket motivasi siswa. Data kualitatif dianalisis secaradeskriptif dan data kuantitatif dianalisis menggunakan statistic deskriptif. Penelitian ini mengahsilkan buku IPA berbasis kearifan lokal Jambi meteri tekanan zat, serta getaran dan gelombang. Kearifan lokal dijadikan sebagai konteks untuk menggali konsep sains. Hasil validasi ahli materi diperoleh skor rata-rata 4,5 dengan kategori "sangat baik" dan ahli media adalah 4,65 dengan kategori "sangat baik". Hasil ujicoba lapangan menunjukkan bahwa buku IPA berbasis kearifan local jambi dapat meningkatkan motivasi belajar siswa dengan skor rata-rata 4,1 (kategori baik).

(C) 2019 Unit Riset dan Publikasi Ilmiah FTK UIN Raden Intan Lampung

Kata Kunci: buku IPA, kearifan lokal jambi, motivasi siswa

\section{PENDAHULUAN}

Pelajaran IPA merupakan ilmu pengetahuan tentang alam yang di peroleh dengan cara yang terkontrol. Menurut Susanto (2013) Ilmu Pengetahuan Alam merupakan usaha manusia memahami alam semesta melalui pengamatan.Dalam memahami pelajaran ilmu pengetahuan alam (IPA) tentu diperlukan adanya kemampuan literasi sains.Menurut Gormally dkk dalam Winata (2016) literasi sains merupakan kemampuan 
seseorang untuk membedakan fakta-fakta sains dari bermacam-macam informasi, mengenal dan menganalisis penggunaan metode penyelidikan serta kemampuan untuk mengorganisasi, menginterpretasikan data kuantitatif dan informasi sains. Kemampuan literasi sains Indonesia masih dikategorikan rendah dibandingkan dengan negara lain. Rendahnya kemampuan literasi sains siswa Indonesia ini tentunya disebabkan oleh beberapa faktor. Salah satu faktor yang bersinggungan langsung dengan kegiatan pembelajaran siswa dan memperngaruhi rendahnya kemampuan literasi siswa Indonesia adalah pemilihan buku ajar (Rosilowati,2015).

Menurut (Situmorang, 2013), "buku ajar adalah buku yang berisi ilmu pengetahuan yang diturunkan darikompetensi dasar yang tertuang dalam kurikulum dan disusun secara sistematis dan digunakan oleh peserta didik untuk belajar.Selain itu buku ajar adalah sumber pembelajaran yang terhubung langsung dengan siswa dan dekat dengan mereka. Selain itu buku ajar adalah bahan-bahan atau materi pembelajaran yang disusun secara sistematis yang digunakan guru dan siswa dalam proses pembelajaran (Pannen dan Purwanto, 2011).

Depdiknas (2011) menyatakan bahwa kecenderungan pembelajaran IPA pada masa kini hanya berorientasi pada produk IPA. Hal ini ditunjukan dengan banyaknya siswa yang mempelajari IPA dengan cara menghapal konsep, prinsip, hukum dan teori yang menyebabkan dimensi sikap, proses, dan aplikasi tidak dapat tercapai secara optimal. Oleh sebab itu pemilihan buku ajar yang sesuai dengan kebutuhan siswa dapat membantu siswa dalam meningkatkan kemampuan pemahaman siswa terhadap pembelajaran IPA.Salah satu bentuk buku ajar yang bisa mempermudah siswa memahami materi pembelajaran IPA dan dapat menciptakan suasana pembelajaran yang menarik adalah buku berbasis kearifan lokal.
Kearifan lokal merupakan ciri khas suatu daerah atau wilayah tertentu yang memiliki nilai kebudayaan, berkembang dalam lingkup lokal dari generasi ke generasi berikutnya (Cristian damayanti, Novi ratna dewi, 2013). Dengan mengintegrasikan kearifan lokal kedalam buku ajar IPA diharapkan siswa lebih mudah memahami konsep pembelajaran IPA dan dapat menambah pengetahuan siswa tentang kearifan lokal Jambi. Selain itu Menurut (Rosala, 2016) dengan pendidikan yang berbasis pada local wisdom (kearifan lokal), maka kita bisa optimis akan terciptanya pendidikan yang mampu memberi makna bagi kehidupan manusia Indonesia. Artinya, pendidikan kemudian akan mampu menjadi spirit yang bisa mewarnai dinamika manusia Indonesia ke depan.

Selain itu pendekatan kontektual juga dipilih sebagai pendekatan yang digunakan dalam penelitian ini.Menurut (Sukarta, Sudiana, \& Sastrawidana, 2010) pendekatan kontekstual adalah konsep pembelajaran yang bertujuan untuk membuat hasil pembelajaran lebih bermakna. Guru diminta untuk bisa mengaitkan antara materi yang diajarkan kedalam situasi dunia nyata siswa sehingga siswa mampu menghubungkan pengetahuan yang dimiliki kedalam kehidupan sehari hari mereka.

Dalam pembelajaran kontekstual melibatkan para siswa dalam aktivitas penting yang membantu mereka mengaitkan pelajaran akademis dengan konteks kehidupan nyata yang mereka hadapi (Amir, 2015). Dengan mengaitkan keduanya, para siswa melihat makna di dalam tugas sekolah. Ketika para siswa menyusun proyek atau menemukan permasalahan yang menarik, ketika mereka membuat pilihan dan menarik tanggung jawab, mencari informasi dan menarik kesimpulan, ketika mereka secara aktif memilih, mempertanyakan, dan membuat keputusan, mereka mengaitkan isi akademis dengan konteks 
dalam situasi kehidupan, dan dengan cara ini mereka menemukan makna.Untuk mendapatkan buku ajar yang sesuai maka dibutuhkan analisis kebutuhan siswa dan guru.karakteristik siswa, sarana pendukung dan materi pembelajaran.

Berdasarkan studi pendahuluan yang dilakukan di SMP N 1 Muaro Jambidengan melakukan observasi dan penyebaran angket kebutuhan guru dan siswa.Hasil observasi menunjukkan bahwa buku ajar yang ada di sekolah masih menggunakan buku ajar IPA terpadu seperti biasa.Hal ini dilihat dari ketersedian buku di perpustakaan.Media yang digunakanpun beragam seperti carta, alat peraga dan lain-lain. Selain itu proses pembelajaran di SMPN 1 Muaro Jambi kebanyakan mencatat dan mendengarkan guru menjelaskan di depan.

Berdasarkan angket kebutuhan, guru menggunakan bahan ajar berupa buku teks dan LKS yang bersumber dari kemendikbud dan penerbit lainnya.Namun buku yang tersedia belum mengintegrasikan materi dan soal soal pembelajaran IPA kedalam kehidupan sehari hari.Buku yang tersedia sudah menjelaskan materi yang cukup mudah dipahami, kegiatan percobaanpun cukup menarik, dan contoh soal yang digunakan sudah membantu memahami materi dengan baik. Berdasarkan angket yang diisi oleh guru mata pelajaran IPA bahwa beliau setuju jika diadakan pengembangan buku ajar berbasis kearifan lokal Jambi untuk kelas VIII karna bisa untuk menambah referensi buku yang sudah ada dan buku yang dikembangkan bisa labih mengintegrasikan pembelajaran IPA dikehidupan sehari- hari dan kearifan lokal.

Hasil angket kebutuhan siswa dihasilkan bahwa materi, kegiatan percobaan dan contoh soal di dalam buku ajar sudah jelas, cukup menarik dan bisa membuat siswa paham. Namun di dalam buku ajar yang tersedia belum terdapat soal-soal literasi sains untuk memperdalam pemahaman peserta didik. Berdasarkan angket kebutuhan, siswa membutuhkan buku ajar tambahan yang menampilkan banyak gambar yang lebih mengintegrasikan pelajaran IPA dengan kearifan lokal Jambi serta terdapat banyak variasi soal untuk meningkatkan pemahaman siswa.

Penelitian ini bertujuan untuk menghasilkan buku ajar IPA materi tekanan zat dan getaran, gelombang dan bunyi berbasis kearifan kearifan lokal Jambi dengan pendekatan kontekstual, sertauntuk meningkatkan motivasi siswa terhadap pembelajran IPA.

\section{METODE PENELITIAN}

Penelitian ini merupakan jenis penelitian pengembangan (research and development). Dalam proses pengembangan peneliti menggunakan model pengembangan ADDIE dari Branch (2009) yang meliputi 5 tahapan yaitu analyze, design, development, implementation dan evaluation. Namun penelitian ini hanya terdapat 3 tahapan yakni tahap analyze, design dan developmen(Branch, 2009).Tahap pertama dalam penelitian ini adalah analisis yang terdiri dari analisis kesenjangan, menentukan tujuan intruksional, analisis karakteristik siswa dan rancangn awal. Tahap kedua adalah design yang terdiri dari menentukan taks inventori, menentukan perpormance objective. Tahap ketiga adalah develop yang teridiri dari validasi ahli materi dan media serta mengetahui motivasi siswa terhadap buku ajar. Subjek penelitian ini adalah ahli materi ,ahli media serta siswa kelas VIII SMPN 1 Muaro Jambi sebanyak 30 siswa. Instrumen yang digunakan dalam penelitian ini yaitu:

1. Observasi dilakukan untuk mengetahui bagaimana proses pembelajaran IPA di kelas, bagaimana ketersediaan buku ajar di sekolah serta mengetahui sarana dan prasarana pendukung pembelajaran 
IPA sepeti laboratorium dan alat peraga.

2. Wawancara dilakukan kepada guru mata pelajaran IPA di SMP 1 Muaro Jambi. Kegiatan ini dilakukan untuk mengetahui tanggapan guru tentang buku ajar yang tersedia, serta mengetahui sikap siswa dalam melaksanakan pembelajaran IPA.

3. Angket kebutuhan guru, kegiatan ini dilakukan untuk mengetahui kebutuhan guru mata pelajaran IPA tentang kebutuhan bahan ajar untuk mencapai tujuan pembelajaran secara maksimal.

4. Angket kebutuhan siswa kegiatan ini dilakukan untuk mengetahui tanggapan siswa terhadap buku ajar yang tersedia, serta mengetahui kebutuhan siswa tentang bahan ajar IPA agar dapat mencapai tujuan pembelajran secara maksimal.

5. Angket validasi ahli digunakan untuk menilai kelayakan buku IPA yang dikembangkan. Aspek yang dinalai meliputi kelayakan isi, penyajian, kegrafikan dan kebahasaan.

Tabel 1. Kisi-kisi Penilaian Aspek Penyajian dan Kebahasaan

\begin{tabular}{|c|c|c|c|}
\hline No & Indikator & $\begin{array}{l}\text { Jumlah } \\
\text { butir }\end{array}$ & $\begin{array}{l}\text { Nomor } \\
\text { butir }\end{array}$ \\
\hline A. & \multicolumn{3}{|c|}{ Komponen Penyajian } \\
\hline 1 & Teknik penyajian & 2 & 1 dan 2 \\
\hline 2 & $\begin{array}{l}\text { Pendukung } \\
\text { penyajian materi }\end{array}$ & 5 & $\begin{array}{l}3,4,5,6 \\
\text { dan } 7\end{array}$ \\
\hline 3 & $\begin{array}{l}\text { Penyajian } \\
\text { pembelajaran }\end{array}$ & 3 & 8,9 , dan 10 \\
\hline 4 & $\begin{array}{l}\text { Kelengkapan } \\
\text { penyajian }\end{array}$ & 3 & $\begin{array}{l}11.12 \text { dan } \\
13\end{array}$ \\
\hline B. & \multicolumn{3}{|c|}{ Komponen Kebahasaan } \\
\hline 1 & $\begin{array}{l}\text { Sesuai dengan } \\
\text { tingkat } \\
\text { perkembangan } \\
\text { siswa }\end{array}$ & 2 & 14 dan 15 \\
\hline 2 & Komunikatif & 1 & 16 \\
\hline 3 & $\begin{array}{l}\text { Dialog dan } \\
\text { interaktif }\end{array}$ & 2 & 17 dan 18 \\
\hline 4 & Lugas & 1 & 19 \\
\hline 5 & $\begin{array}{ll}\text { Koherasi } & \text { dan } \\
\text { keruntunan } & \text { alur } \\
\text { piker } & \end{array}$ & 1 & 20 \\
\hline
\end{tabular}

\begin{tabular}{llll}
\hline 6 & $\begin{array}{l}\text { Kesesuaian } \\
\text { dengan kaidah } \\
\text { bahasa Indonesia }\end{array}$ & 1 & 21 \\
7 & $\begin{array}{l}\text { Penggunaan } \\
\text { istilah dan } \\
\text { symbol }\end{array}$ & 1 & 22 \\
\hline
\end{tabular}

Tabel 2. Kisi-kisi Penilaian Aspek Kegrafikan

\begin{tabular}{llrl}
\hline No & Indikator & $\begin{array}{l}\text { Jumlah } \\
\text { butir }\end{array}$ & $\begin{array}{l}\text { Nomor } \\
\text { butir }\end{array}$ \\
\hline 1 & Ukuran Buku & 2 & 1 dan 2 \\
2 & $\begin{array}{l}\text { Desain kaver } \\
\text { buku ajar }\end{array}$ & 7 & $3,4,5,6$, \\
3 & $\begin{array}{l}\text { Desain isi buku } \\
\text { ajar }\end{array}$ & 15 & $12,13,14$, \\
& & & $15,16,17$, \\
& & & $18,19,20$, \\
& & & $21,22,23,25$ dan \\
& & & 26 \\
\hline
\end{tabular}

Tabel 3. Kisi-kisi Penilaian Aspek Kelayakan Isi

\begin{tabular}{|c|c|c|c|}
\hline No & Indikator & $\begin{array}{l}\text { Jumlah } \\
\text { butir }\end{array}$ & $\begin{array}{l}\text { Nomor } \\
\text { butir }\end{array}$ \\
\hline 1 & $\begin{array}{ll}\text { Dimen } & \text { sikap } \\
\text { spiritual } & \end{array}$ & 2 & 1 dan 2 \\
\hline 2 & $\begin{array}{l}\text { Dimensi sikap } \\
\text { social }\end{array}$ & 2 & 3 dan 4 \\
\hline 4 & Cakupan materi & 3 & 5,6 dan 7 \\
\hline 5 & Akurasi materi & 3 & 8,9 dan 10 \\
\hline 7 & $\begin{array}{l}\text { Ketaatan hukum } \\
\text { dan perundang } \\
\text { undangan }\end{array}$ & 1 & 11 \\
\hline 8 & $\begin{array}{l}\text { Pendeukung } \\
\text { penyajian materi }\end{array}$ & 7 & 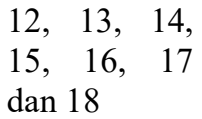 \\
\hline
\end{tabular}

Data kualitatif dianalisis secaradeskriptif dan data kuantitatif dianalisis menggunakan statistic deskriptif.

\section{HASIL DAN PEMBAHASAN}

Penelitian ini menggunakan model pengembangan ADDIE dengan alur Analysis, Design, Development, Implementation, dan evaluation.Namun pada penelitian ini tahap implementation dan evaluation tidak dilakukan. Berikut dijelaskan mengenai hasil dari setiap langkah pengembangan menggunakan model ADDIE:

\section{Analisis}

Menurut Branch (2009), tujuan dari tahap analisis adalah untuk mengetahui pokok masalah dari performance gap yang terjadi pada suatu phenomena dan 
merekomendasikan solusi yang sesuai dengan kondisi yang ada. Pada tahap ini, hal yang dilakukan adalah 1) validasi kesenjangan, 2) analisis karakteristik siswa, 3) analisis sumber daya pendukung, dan 4) menyusun rencana kerja.

Dari tahap validasi kesenjangan ditemui beberapa pokok permasalahan pada bahan ajar mata pelajaran IPA fisika kelas VIII semester II. Menurut Branch (2009),Validasi kesenjangan bertujuan untuk menghasilkan pernyataan tujuan secara umum berdasarkan performance gap yang ditemukan pada sumber belajar. Berdasarkan truangulasi pada hasil observasi awal, wawancara guru dan analisis dokumen bahan ajar yang selama ini digunakan maka peniliti menemukan beberapa permasalahan yaitu:

Minimnya ketersediaan buku ajar, (2) Materi pembelajaran yang tidak dikaitkan dengan kehidupan sehari-hari siswa, dan (3) Soal uji kompetensi yang tidak sinkron dengan materi.

Tahap selanjutnya adalah menentukan tujuan instruksional.Branch (2009) menyatakan bahwa, tujuan dari menentukan tujuan instruksional adalah untuk merespon kesenjangan yang disebabkan oleh kurangnya pengetahuan dan keterampilan yang ditemukan pada performance gap.Pada tahap ini dirumuskan indikator dan tujuan pembelajaran IPA pada materi tekanan zat, dan getaran, gelombang dan bunyi dalam kehidupan sehari-hari.

Setelah menentukan tujuan instruktional dilakukanlah analisis karakteristik siswa agar buku IPA fisika berbasis kearifan lokal Jambi yang akan digunakan tepat sasaran, dapat diterima, mudah dimengerti dan dapat digunakan dalam kegiatan pembelajaran IPA kelas VIII semester II. Hal ini dilakukan melalui penyebaran angket sikap dan kebutuhan siswa.
Berdasarkan hasil angket kebutuhan siswa yang diberikan kepada 43 siswa di kelas VIII menunjukkan bahwa 100\% siswa sudah memiliki 1 buku ajar yang dipinjamkan oleh pihak sekolah dan $80 \%$ sudah membacanya. Dalam sehari ratarata siswa membaca dan menggunakan buku ajar IPA selama 1 jam.Data lain yang dihasilkan merupakan pendapat siswa terhadap buku ajar yang tersedia. Berikut data hasil angket pendapat siswa Gambar 1.

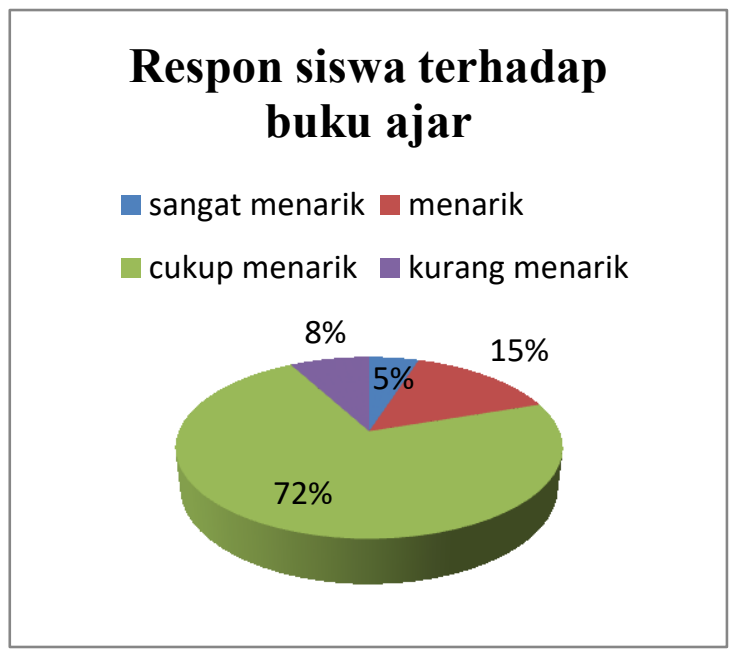

Gambar 1. Grafik hasil data angket siswa

Pada grafik di atas terlihat bahwa pendapat siswa tentang buku ajar yang tersedia adalah $75 \%$ cukup menarik. Berarti aspek-aspek yang terdapat di dalam buku ajar seperti gambar, percobaan dan materi perlu ditingkatkan lagi agar bisa menjadi lebih menarik. Menurut siswa buku yang tersedia mudah dipahami dan cukup membantu siswa dalam memahami materi. Hasil lain berdasarkan angket menyatakan bahwa $90 \%$ siswa berpendapat belum adanya soal literasi sains didalam buku yang tersedia selain itu hasil menjukkan bahwa $85 \%$ siswa membutuhkan buku ajar tambahan guna menambah referensi yang sudah ada. Adapun buku ajar yang diharapkan oleh siswa untuk menambah referensi buku yang sudah ada dapat dilihat pada Gambar 2 


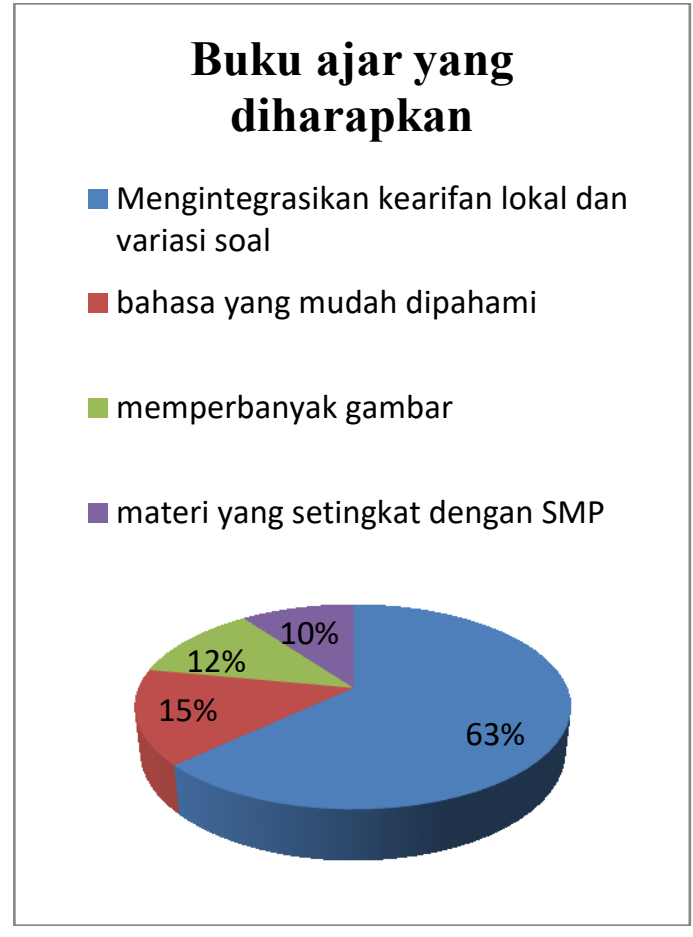

Gambar 2. Grafik harapan buku ajar tambahan Pada grafik di atas dapat dilihat bahwa $63 \%$ siswa menyatakan bahwa buku yang diharapkan berupa buku ajar IPA yang mengintegrasikan pembelajaran dengan kearifan lokal jambi yang ada di sekitar mereka selain itu buku ini diharapkan memiliki variasi soal yang beragam seperti soal literasi sains agar siswa terbiasa dalam menyelesaikan soalsoal literasi.Menurut Asyhari dan Hartati (2015) literasi sains merupakan kemampuan menggunakan pengetahuan sains, mengidentifikasi pertanyaan, dan menarik kesimpulan berdasarkan buktibukti, dalam rangka memahami serta membuat keputusan berkenaan dengan alam dan perubahan yang dilakukan terhadap alam melalui aktivitas manusia.

\section{Desain}

Tahap perancangan atau tahap desain ini bertujuan untuk memverifikasi keadaan (tujuan instruksional) yang diinginkan dan metode (evaluasi) ketecapaiannya dengan tepat (Branch, 2009). Adapun prosedur yang dilakukan oleh peneliti pada tahap ini adalah: (1) Menentuksn task inventory (spesifikasi tjuan instruksional yang diinginkan), (2) Menentukan performance objective (kriteria yang diinginkan pada setiap spesifikasi tujuan instruksional), (3) Menyusun testing strategies (cara melakukan evaluasi ketercapaian pada setiap spesifikasi tujuan instruksional yang diinginkan) dan (4) Menghitung estimasi biaya.

\section{Develop}

Pada tahap pengembangan ini dilakukan validasi ahli untuk menghasilkan buku ajar yang layak untuk diuji cobakan.Validasi ahli materi dan media buku ajar IPA fisika berbasis kearifan lokal dengan pendekatan kontekstual untuk siswa SMP kelas VIII semester II ini dilakukan oleh dua orang dosen Pendidikan Fisika Universitas Jambi.Validator ahli materi mengisi angket yang berisi 6 indikator dengan 18 pertanyaan. Sedangkan validator ahli media mengisi 2 angket yang terdiri dari angket aspek kebahasaan yang berisi 9 indikator penilaian dengan 17 pertanyaan dan aspek kegrafikan yang berisi 7 indikator dengan 26 pertanyaan. Dimana validator mengisi salah satu kolom penilaian dengan skala 1, 2, 3, 4 dan 5 untuk setiap butir pertanyaan dengan cara menceklisnya dan memberikan saran untuk perbaikan baik dari segi materi maupun media.

Berdasarkan analisis validasi ahli menunjukkan bahwa skor yang diperoleh pada validasi materi tahap I yaitu skor rata-rata indikator keseluruhan yang diberikan oleh validator adalah 3,08 yang dikategorikan kurang baik. Oleh sebab itu agar produk layak untuk diujicobakan maka perlu diadakan validasi tahap II yang beracuan pada saran yang telah diberikan oleh validator ahli materi.

Dari validasi aspek materi tahap II dihasilkan skor rata-rata indikator keseluruhan adalah 4,1 yang dikategorikan baik dan layak untuk diuji cobakan. Namun ada beberapa bagian yang harus diperbaiki sehingga perlu 
diadakan validasi tahap III. Hasil validasi materi tahap III dapat dilihat pada tabel 4.

Tabel 4. Hasil Validasi Aspek Kelayakan Isi

\begin{tabular}{|c|c|c|c|}
\hline No. & Indikator & $\begin{array}{l}\text { Rerata } \\
\text { Skor }\end{array}$ & Kategori \\
\hline 1 & $\begin{array}{l}\text { Dimensi sikap } \\
\text { spiritual }\end{array}$ & 4,5 & $\begin{array}{l}\text { Sangat } \\
\text { Baik }\end{array}$ \\
\hline 2 & $\begin{array}{l}\text { Dimensi sikap } \\
\text { social }\end{array}$ & 4,3 & Baik \\
\hline 3 & $\begin{array}{l}\text { Dimensi } \\
\text { pengetahuan }\end{array}$ & 4,3 & $\begin{array}{l}\text { Sangat } \\
\text { Baik }\end{array}$ \\
\hline 4 & Akurasi materi & 4,6 & $\begin{array}{l}\text { Sangat } \\
\text { Baik }\end{array}$ \\
\hline 5 & $\begin{array}{l}\text { Ketaatan pada } \\
\text { hokum dan UUD }\end{array}$ & 5 & $\begin{array}{l}\text { Sangat } \\
\text { Baik }\end{array}$ \\
\hline 6 & $\begin{array}{l}\text { Pendukung } \\
\text { penyajian materi } \\
\text { Jumlah }\end{array}$ & $\begin{array}{l}4,8 \\
4,5\end{array}$ & $\begin{array}{l}\text { Sangat } \\
\text { Baik } \\
\text { Sangat } \\
\text { Baik }\end{array}$ \\
\hline
\end{tabular}

Berdasarkan tabel diatas dapat disimpulkan bahwa produk layak diuji cobakan kepada siswa SMP kelas VIII semester II tanpa revisi.Produk terkategorikan sangat baik dengan skor rata-rata indikator keseluruhan adalah 4.5 dan layak untuk diuji cobakan tanpa adanya revisi.

Selanjutnya dilakukan validasi ahli media, hasil validasi ahli media tahap I aspek kebahasaan diperoleh skor 3,5 yang dikategorikan baik, namun masih perlu dilakukan revisi dibeberapa perangkat pengembangan sebelum dilakukan ujicoba. Berdasarkan saran dari validator maka dilakukanlah validasi media aspek kebahasaan tahap II. Hasil validasi ahli media aspek kebahasaan dapat dilihat pada tabel 5 .

Tabel 5. Hasil Validasi Aspek Kebahasaan

\begin{tabular}{|c|c|c|c|}
\hline No & Indikator & $\begin{array}{l}\text { Rerata } \\
\text { Skor }\end{array}$ & Kategori \\
\hline 1 & Teknik penyajian & 4 & Baik \\
\hline 2 & $\begin{array}{l}\text { Penyajian } \\
\text { pembelajaran }\end{array}$ & 4,3 & Baik \\
\hline 3 & $\begin{array}{l}\text { Kelengkapan } \\
\text { penyajian }\end{array}$ & 4,3 & Baik \\
\hline 4 & $\begin{array}{l}\text { Sesuai dengan } \\
\text { perkembangan } \\
\text { peserta didik }\end{array}$ & 4,5 & Baik \\
\hline 5 & Komunikatif & 5 & $\begin{array}{l}\text { Sangat } \\
\text { Baik }\end{array}$ \\
\hline
\end{tabular}

\begin{tabular}{llll}
\hline 6 & Dialogis interaktif & 4,5 & Baik \\
7 & Lugas & 4 & Baik \\
8 & Kohesi dan & 5 & Sangat \\
& $\begin{array}{l}\text { keruntunan alur } \\
\text { piker }\end{array}$ & & Baik \\
9 & $\begin{array}{l}\text { Kesesuaian dengan } \\
\text { kaidah }\end{array}$ & 5 & $\begin{array}{l}\text { Sangat } \\
\text { Baik }\end{array}$ \\
10 & $\begin{array}{l}\text { Penggunaan istiah } \\
\text { dan } \\
\text { symbol/lambing }\end{array}$ & 4 & Baik \\
& & \\
& Jumlah & 4,9 & Sangat \\
& & Baik \\
\hline
\end{tabular}

Berdasarkan tabel diatas dapat disimpulkan bahwa produk dari aspek kebahasaan, sudah layak untuk diujicobakan tanpa revisi karena produk dikategorikan sangat baik dengan skor rata-rata indikator keseluruhan yaitu 4,9.

Analisis hasil validasi ahli media aspek kegrafikan tahap I dihasilkan skor rata-rata indikator keseluruhan yaitu 3,8 yang dikategorikan baik, namun perlu dilakukan revisi sebelum dilakukan ujicoba. Agar buku ajar IPA fisika berbasis kearifan lokal Jambi layak diujicobakan sesuai dengan komentar dan saran yang telah diberikan oleh validator ahli maka dilakukan validasi tahap II. Hasil validasi ahli media tahap II aspek kegrafikan dapat dilihat pada tabel 6 .

Tabel 6. Hasil Aspek Kegrafikan

\begin{tabular}{llll}
\hline No. & Indikator & $\begin{array}{l}\text { Skor } \\
\text { rata- } \\
\text { rata }\end{array}$ & Kategori \\
\hline 1 & $\begin{array}{l}\text { Ukuran buku } \\
\text { Tata letak }\end{array}$ & 4,5 & $\begin{array}{l}\text { Sangat Baik } \\
\text { cover buku } \\
2\end{array}$ \\
3 & $\begin{array}{l}\text { Tipografi cover } \\
\text { buku }\end{array}$ & Sangat Baik \\
4 & $\begin{array}{l}\text { Ilustrasi kulit } \\
\text { buku }\end{array}$ & Sangat Baik \\
5 & $\begin{array}{l}\text { Desain isi buku } \\
\text { Tipografi isi }\end{array}$ & 4,4 & Baik \\
6 & $\begin{array}{l}\text { buku } \\
\text { Ilustrasi Buku }\end{array}$ & Saik \\
& Jumlah & 4,4 & Sangat Baik \\
& & & Sangat Baik \\
\hline
\end{tabular}

Berdasarkan tabel diatas maka dapat disimpulkan bahwa dari aspek kegrafikan produk sudah layak untuk diujicobakan tanpa revisi karena produk dikategorikan 
sangat baik dengan skor rata-rata indikator keseluruhan yaitu 4.4. Setelah melalui proses validasi, buku ajar IPA fisika berbasis kearifan lokal dengan pendekatan kontekstual dikategorikan baik dari segi materi dan media. Adapun tahapan selanjutnya adalah melakukan uji persepsi siswa.

Hasil analisis motivasi siswa terhadap buku ajar menunjukkan bahwa buku ajar IPA materi tekanan zat dan getaran, gelombang, bunyi berbasis kearifan lokal Jambi yang telah dikembangkan dikategorikan dapat memotivasi siswa. Skor rata-rata yang diperoleh dari indikator keseluruhan adalah 4,1 yang dikategorikan sangat baik. Selain itu juga buku ajar inidapat digunakan sebagai buku ajar tambahan sebagai referensi tambahan dari buku yang sudah ada. Adapun tampilan akhir produk akhir setelah melalui revsisi dan uji coba adalah sebagai berikut

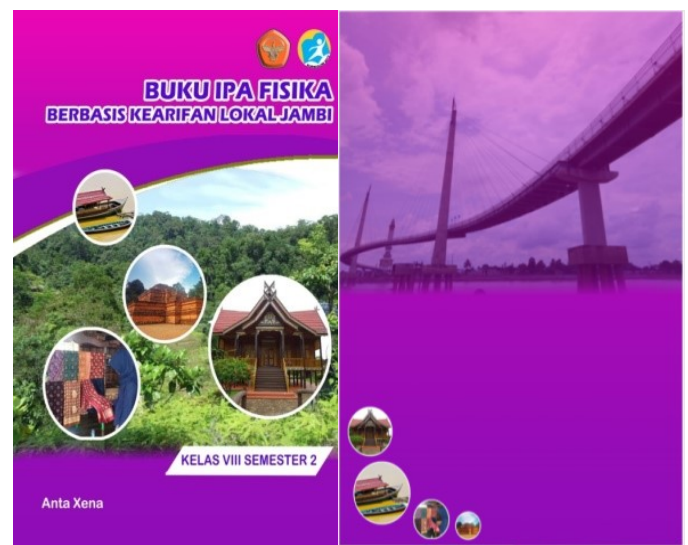

Gambar 3. Cover Depan

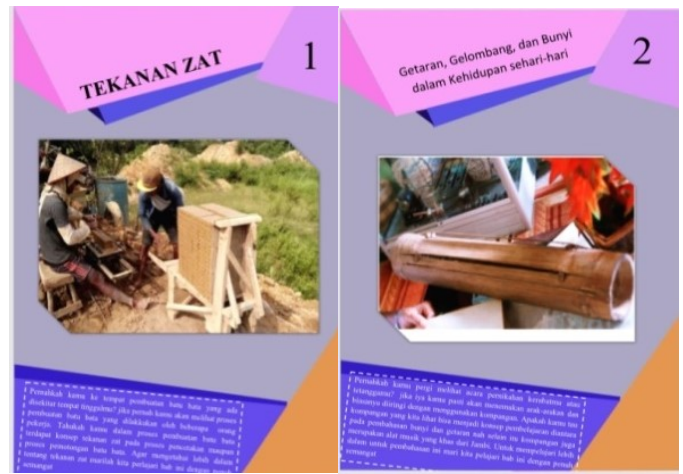

Gambar 4. Cover bab I dan bab II
Penelitian ini bertujuan untuk menghasilkan buku ajar IPA fisika berbasis kearifan lokal Jambi kelas VIII semester II serta menguji kelayakan produk yang dihasilkan. Menurut Brown (2009) langkah-langkah proses pada penelitian dan pengembangan ini meliputi tahap analisis, desain, develop, implementasi dan evaluasi. Namun dalam penelitian ini tahap implementasi dan evaluasi tidak dilakukan. Tahap pertama dalam penelitian ini adalah tahap analisis yang dilakukan untuk mengetahui kebutuhan siswa dan guru terhadap kebutuhan buku ajar IPA.Pada tahap ini diperoleh sebesar $90 \%$ siswa menyatakan bahwa belum terdapat soal literasi sains di dalam buku ajar yang tersedia. (Situmorang, 2013) menyatakan bahwa literasi sains tidak bisa lepas dari pendidikan sains.Keterkaitan keduanya menjadi bagian yang bersifat holistik dalam mewujudkan pembelajaran sains yang lebih bermakna. Selain itu dari hasil angket juga diperoleh $85 \%$ siswa membutuhkan buku ajar tambahan untuk menambah referensi yang sudah ada dan $63 \%$ siswa mengharapkan buku ajar yang diintegrasikan dengan kearifan lokal Jambi. Hal ini sesuai dengan pendapat Pertiwi, dkk (2018) bahwa media pembelajaran sebaiknya dipilih sesuai tujuan pembelajaran, materi ajar dan karakteristik peserta didik sebagai subjek pembelajaran.Oleh sebab itu, dilakukan pengembangan produk berupa buku ajar IPA fisika berbasis kearifan lokal Jambi.

Tahap selanjutnya adalah tahap desain.Pada tahap ini, produk berupa buku ajar IPA fisika berbasis kearifan lokal Jambi dengan menggunakan pendekatan kontekstual dirancang. Trianto (2008) dalam Situmorang (2016) implementasi pembelajaran sains harus menekankan aspek kontekstual dan berbasis pada permasalahan-permasalahan yang berkaitan dengan kehidupan seharihari.Hal ini sejalan dengan pendapat Johnson (2002) pendekatan konstektual 
bertujuan untuk membantu siswa memahami materi pembelajaran dengan menghubungkan pembelajaran dalam konteks kehidupan sehari-hari, seperti konteks keadaan pribadi, sosial dan budaya mereka.Dalam hal ini pengintegrasian pembelajaran IPA kedalam kearifan lokal Jambi dipilih agar siswa lebih mudah memahami materi pembelajaran karena contoh-contoh yang ditampilkan merupakan hal-hal yang berada disekitar mereka dan dengan adanya buku ajar ini siswa dapat mengenal kearifan lokal Jambi yang selama ini belum mereka ketahui. Hal ini sejalan dengan pendapat (Cristian damayanti, Novi ratna dewi, 2013)) bahwa kearifan lokal sebagai salah satu hal yang perlu dilestarikan, artinya perlu dijaga, dilindungi, dan dilestarikan agar tidak punah maka pengintegrasian kearifan lokal dalam pembelajaran perlu dilakukan untuk mencegah hilangnya kearifan lokal suatu daerah. Penggunaan bahasan yang mudah dimengerti dan sistematis dengan menyajikan permasalahan atau peta konsep pada awal tiap bab sehingga dapat mempermudah siswa dalam memahami suatu konsep atau memantapkan susatu konsep. Menurut Wolff, M.R, \& Anita, (2012) yang menyatakan bahwa salah satu cara untuk mengembangkan strategi belajar mengajar bermakna adalah menggunakan peta konsep atau pemetaan konsep. Buku ajar IPA fisika ini menyajikan materi dengan layout dan gambar-gambar yang menarik untuk menarik minat siswa dalam pembelajaran IPA.

Tahap ketiga adalah tahap pengembangan (develop), pada tahap ini dikembangkan produk buku ajar IPA berbasis kearifan lokal Jambi kelas VIII semester II. wWarpala (2009) dalam Anggramayeni, dkk (2018) menyatakan bahwa bahan ajar berbasis kearifan lokal dapat memberi konstribusi yang positif untuk meningkatkan pemahaman konsep dan kinerja siswa.Oleh sebab itu, melalui penelitian ini nantinya diharapkan dapat menarik minat siswa dalam pembelajaran IPA, membantu siswa memahami konsep IPA dengan baik dan memberikan latihan yang cukup.Analisis kurikulum dan materi dilakukan untuk mengetahui kurikulum yang digunakan, mengetahui kompetensi inti dan kompetensi dasar serta mengetahui materi-materi pelajaran IPA yang dapat diintegrasikan kedalam kearifan lokal Jambi.Selanjutnya atas saran dari dosen pembimbing agar produk dapat dikembangkan dengan baik dan sesuai dengan bahna kajian dalam silabus.Menurut Sagala (2008) silabus merupakan pengambangan kurikulum yang menjabarkan standar kompetensi dan kompetensi dasar yang ingin dicapai, pokok-pokok dan uraian materi yang perlu dipelajari peserta didik.Maka berdasarkan kajian dalam silabus ada dua materi pembelajaran yang dapat diintegrasikan dengan kearifan lokal Jambi yakni tekanan zat dan getaran, gelombang dan bunyi dalam kehidupan sehari-hari.

Setelah dilakukan pengembangan maka buku ajar diuji kelayakan dengan melakukan validasi ahli media dan ahli materi serta dilakukan ujicoba kepada siswa SMP kelas VIII. Validasi yang dilakukan merupakan proses penilaian rancangan dari produk yang dikembangkan dengan memberikan penilaian berdasarkan pemikiran rasional, tanpa uji coba lapangan. Buku ajar IPA fisika berbasis kearifan lokal Jambi divalidasi beberapa kali oleh tim ahli materi dan ahli media yang terdiri dari dua dosen Pendidikan Fisika Universitas Jambi, JF dan FRB. Validator ini memberikan penilaian dengan mengisi angket tertutup yang sebelumnya sudah disediakan serta memberikan saran, kritik, penilaian dan masukan terhadap buku ajar IPA fisika yang telah dikembangkan.

Buku ajar IPA fisika berbasis kearifan lokal Jambi pada materi tekanan zat, getaran, gelombang dan bunyi pada 
kehidupan sehari-hari yang dikembangkan belum dilakukan tahap implementation dan evaluation, sehingga belum dapat mengetahui hasil belajar siswa menggunakan buku ajar yang dikembangkan sudah mampu meningkatkan kemampuan literasi sains siswa atau belum. Oleh sebab itu, disarankan kepada peniliti selanjutnya untuk dapat melajutkan tahapan berikutnya yaitu implementation dan evaluation untuk mengetahui peningkatan kemampuan literasi sains siswa setelah menggunakan buku ajar IPA fisika berbasis kearifan lokal Jambi ini.

\section{KESIMPULAN}

1. Pengembangan buku ajar IPA materi tekanan zat daagetran gelombang, bunyi berbasis kearifan lokal dengan pendekatan kontekstual kelas VIII semester II dilakukan dengan menggunakan model pengembangan yaitu: analyze, design, development, imolementation dan evaluation namun implementation dan evalution tidak dilakukan. Keunggulan dari buku ajar IPA fisika yang dikembangkan adalah adanya pengintegrasian kearifan lokal Jambi kedalam pembelajaran IPA disertai dengan gambar-gambar kearifan lokal Jambi yang berada disekeliling mereka dan dilengkapi dengan adanya soal literasi sains sehingga siswa dapat lebih mudah memahami materi pembelajaran.

2. Buku ajar IPA materi tekanan zat dan getaran, gelombang dan bunyi berbasis kearifan lokal Jambi divalidasi oleh ahli materi dan ahli media. Hasil validasi terhadap materi adalah 4,5 dengan kategori "baik sekali" dan ahli media adalah 4,9 dan 4,4 dengan kategori "baik sekali". Selanjutnya hasil angket validasi materi dan media dapat disimpulkan bahwa buku ajar IPA fisika berbasis kearifan lokal Jambi ini layak untuk diujicobakan untuk meningkatkan motivasi siswa.
3. Dari angket motivasi siswa untuk buku ajar IPA fisika berbasis kearifan lokal Jambi dengan pendekatan kontekstual yang diujicobakan kepada 30 siswa kelas VIII di SMP 1 Muaro Jambi di hasilkan bahwa buku yang di kembangkan dapat memotivasi siswa terhadap pembelajaran IPA dengan konten kearifan lokal Jambi yang disajikan. Skor rata-rata keseluruhan angket motivasiyang diperoleh adalah.

\section{DAFTAR PUSTAKA}

Amir, M. faizal. (2015). Pengaruh pembelajaran kontekstual terhadap kemampuan pemecahan masalah matematika siswa sekolah dasar. Prosiding Seminar Nasional Pendidikan, 34-42.

Branch, R. M. Intructional Desight-The ADDIE Approach. New York: Springer.

Cristian damayanti, Novi ratna dewi, I. akhlis. (2013). Pengembangan CD pembelajaran berbasis kearifan lokal tema getaran dan gelombang untuk siswa SMP kelas VIII. Unnes Science Education Journal, 2(2), 274-281.

Johnson, E.B (2002) Contextual teaching and learning. California: Corwin Press Inc.

Nuraini, Asriati. 2012. "Mengembangkan Karakter Peserta Didik Berbasis Kearifan Lokal Melalui Pembelajaran di Sekolah". Jurnal Pendidikan Sosiologi dan Humaniora: 27-28.

Pannen, paulina dan purwanto. (2001) Penulisan bahan ajar, Jakarta : pusat antar Universitas untuk meningkatkan dan pengembangan aktivitas intruksional Dirjen Dikti Diknas

Rosala, D. (2016). Pembelajaran seni budaya berbasis kearifan lokal dalam upaya membangun pendidikan karakter siswa di sekolah dasar. Ritme, 2(1), 17-26. 
Rosala, Dedi. 2016 Pembelajaran seni budaya berbasis kearifan lokal dalam upaya membangun pendidikan karakter siswa sekolah dasar.Jurnal seni dan desain.2 (1).

Situmorang, M. (2013). Pengembangan Buku Ajar Kimia Sma Melalui Inovasi Pembelajaran Dan Integrasi Pendidikan Karakter Untuk Meningkatkan Hasil Belajar Siswa. Prosiding Semirata FMIPA Universitas Lampung, 237-246.

Sukarta, I. N., Sudiana, I. K., \& Sastrawidana, I. D. K. (2010). Penerapan pendekatan kontekstual menggunakan model kooperatif pada pembelajaran kimia dan pencemaran lingkungan. Jurnal Pendidikan Dan Pengajaran, (3), 199-206. 